Energy Analysis

\section{International Trade of Biofuels}

\section{Market Overview}

In recent years, the production and trade of biofuels have increased to meet global demand for renewable fuels. Ethanol and biodiesel contribute much of this trade because they are the most established biofuels, but there is potential for trade of infrastructure-compatible biofuels in the future if that industry develops.

Ethanol has been traded for decades and has developed into a global market involving large volumes (Heinimo and Junginer 2009). In contrast, biodiesel trade is less established and has been encouraged by increases in policies and incentives that promote biofuels, particularly in the European Union (EU). The current major participants in the liquid biofuels trade are the United States, the EU, Brazil, and Argentina. The volume and direction of biofuel trade depend on many factors, including policies, tariffs, and crop yields. Figure 1 shows an influence diagram for the trade of liquid biofuels, focusing on the United States.

\section{Policies}

Policies for the promotion of biofuels can be categorized into three major groups with various subcategories (Lamers et al. 2011):

- Promotion of domestic consumption, including:

- Consumption mandates

○ Incentives, such as tax exemptions for biofuels or incentives promoting flex-fuel vehicles

- Promotion of domestic production, including:

- Production mandates

$\circ$ Investment support, such as loan guarantees and tax credits for biofuels facilities and research and development

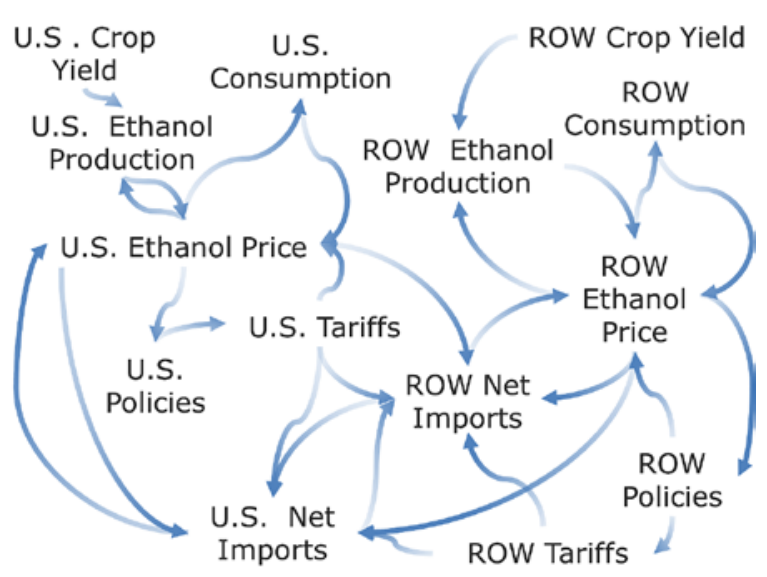

Figure 1. Influence diagram of biofuels trade between the United States and the rest of the world (ROW). The diagram shows factors that influence the net imports and point-of-use price of biofuels in the United States.

$\circ$ Feedstock support

$\circ$ Tax incentives

- Trade-related measures, including:

o Protective actions, such as import tariffs

- Measures to prevent exports, such as export tariffs.

All of these policy types have been used to affect the trade stream of biofuels among the major countries. Some of the most significant policies in effect are the EU's Renewable Energy Directive (RED) and international tariffs; the United States had a significant tariff on Brazilian ethanol imports that expired at the end of 2011. These policies greatly influence where biofuels are imported and produced. For example, RED has caused much more demand for biodiesel imports in the EU while the price for biodiesel in the United States has not been competitive with petroleum-based diesel.

\section{United States}

In 2005, the United States surpassed Brazil as the largest producer of ethanol (Heinimo and Junginer 2009). However, the United States was still a net importer of ethanol until 2010 likely due to increased demand caused 
Figure 2. U.S. ethanol trade balance 2000-2010 (EIA 2012)

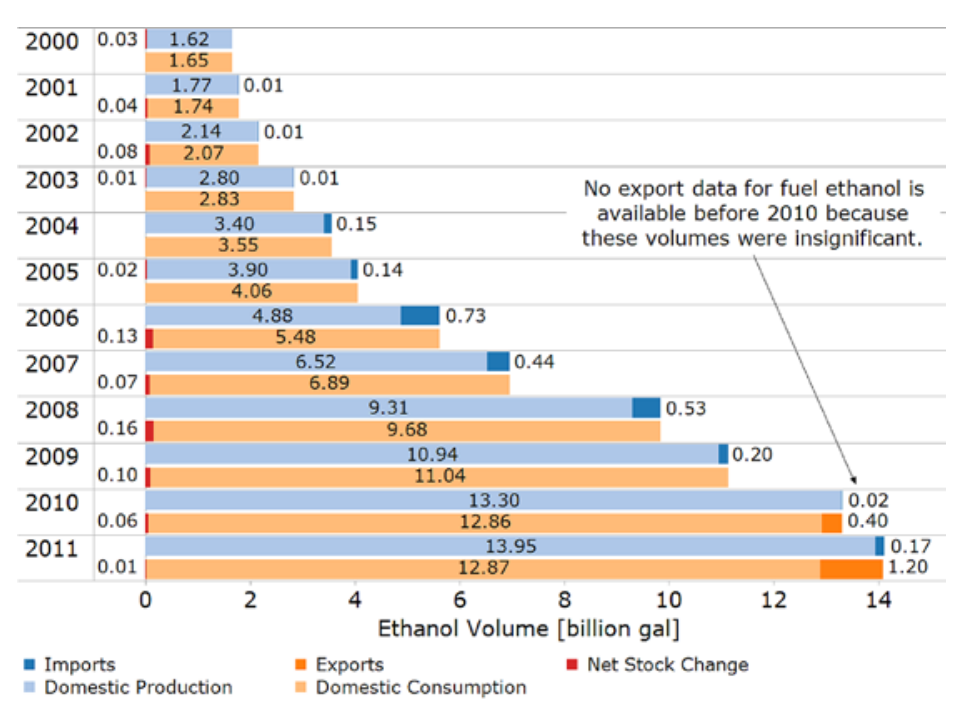

by the initial renewable fuel standard (RFS) mandates, elevated petroleum prices, and environmental concerns. The U.S. fuel ethanol trade balance is shown in Figure 2. In 2010 and 2011, the United States was a net exporter, which was primarily due to Brazil's low crop yields (U.S. International Trade Commission 2011). High exports are expected to continue, as the amount of ethanol that can be blended with gasoline is saturated and the demand for ethanol in the EU continues to grow (Junginger et al. 2008). The majority of ethanol imports in the United States have come from Brazil despite specific tariffs against Brazilian ethanol. High imports have been attributed to the relatively low cost to produce ethanol from sugar cane in Brazil and the ability to avoid some tariffs by dehydrating the ethanol in Caribbean countries that have trade agreements with the United States (U.S. International Trade Commission 2011). However, imports from Brazil have the potential to increase with the expiration of the tariff at the end of 2011.

In contrast to ethanol trade, the United States became a net exporter of biodiesel in 2007, as shown in Figure 3. Most of the limited imports come from Argentina, as well as lesser amounts from Malaysia and Indonesia, and are re-exported to the EU, which has a much higher demand for biodiesel due to biofuels mandates. Demand for biodiesel in the United States is likely limited because of the focus of current policies on domestic ethanol production. With the expiration at the end of 2011 of the ethanol blenders credit - the Volumetric Ethanol Excise Tax-the incentive to consume ethanol domestically may decrease, and U.S. biodiesel consumption may become more prevalent. Currently, biodiesel imports also do not have a tariff, which allows Argentinean biodiesel to be imported to the United States and blended before being exported to the EU (Junginger et al. 2008).

\section{European Union}

The EU has been a major consumer of both biodiesel and ethanol since 2003, and the acceptance of RED in 2009 has only increased the production and consumption of biofuels. RED requires a $10 \%$ renewable energy share in the transportation sector by 2020 and outlines sustainability criteria, which include land use change and greenhouse gas (GHG) savings. In addition to RED, the EU's Fuel Quality Directive also created requirements for renewable fuel use - including a $6 \%$ reduction in transportation-related GHG emissions-and dictated fuel quality standards. The technical standards from the Fuel Quality Directive in conjunction with the sustainability requirements may increase barriers to trade but at the same time increase consistency in fuel quality and provide certainty for producers and consumers (Lamers et al. 2011). Currently, only direct land use change is considered in both regulations, but future revisions may include indirect land use change (Lamers et al. 2011). These changes could greatly limit what sources of biomass are considered sustainable and count toward RED requirements, which

Figure 3. U.S. biodiesel trade balance 2001-2010 (EIA 2012)

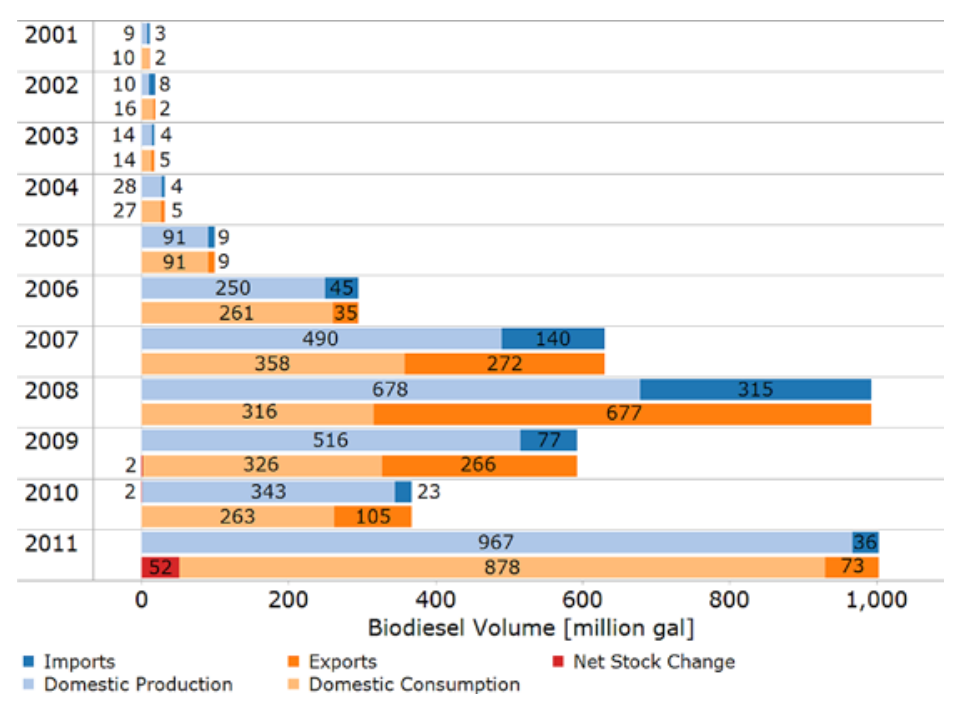


could have large implications for the import of biofuels to the EU. Current legislation under consideration proposes that only $5 \%$ of total EU transportation energy would be allowed to originate from crop-based biofuels (Dunmore 2012). This policy would severely limit growth of imports to the EU of ethanol and biodiesel as approximately $4.5 \%$ of total EU transportation energy already comes from food crop-based biofuels; however, it may lead to faster development of non-crop-land-using biofuels and the establishment of large-scale advanced biofuels trade.

Large volumes of ethanol and biodiesel must be imported to the EU, despite high production of biodiesel within the EU and high level of trade among EU members (see Figures 4 and 5) (Lamers et al. 2011). Currently, EU members are the main consumers of biodiesel and significant consumers of ethanol. Unless there are significant changes in biofuels sustainability requirements, high imports of biofuels are likely to continue due to strong mandates for GHG reductions and an inability to supply enough biofuels within the EU (Lamers et al. 2011).

\section{Brazil}

Brazil has maintained strong ethanol production and exports since the 1970s. Although ethanol production was historically focused on beverages and sugars, in the last 10 years ethanol supply has turned toward fuel (Junginger et al. 2008). Despite aggressive policies to encourage domestic consumption, Brazil still historically exported large quantities of fuel ethanol to the United States and the EU. However, in 2010 and 2011, Brazil was a net importer of ethanol; this change was likely due to low sugarcane crop yields, which is Brazil's primary biofuels feedstock, and high sugar prices. India's poor sugar crop yields drove up global sugar product prices, diverting sugarcane feedstock in Brazil from ethanol production to edible sugar production (U.S. International Trade Commission 2011). In these years, Brazil primarily imported ethanol from the United States and curtailed some of its consumption-based policies to avoid large price increases.

Brazil also produces some biodiesel, which is consumed almost entirely domestically due to the remote locations of production, the high price of transportation, and varying technical standards among countries (Lamers et al. 2011).
Figure 4. EU ethanol trade balance 2000-2009 (Lamers et al. 2011)

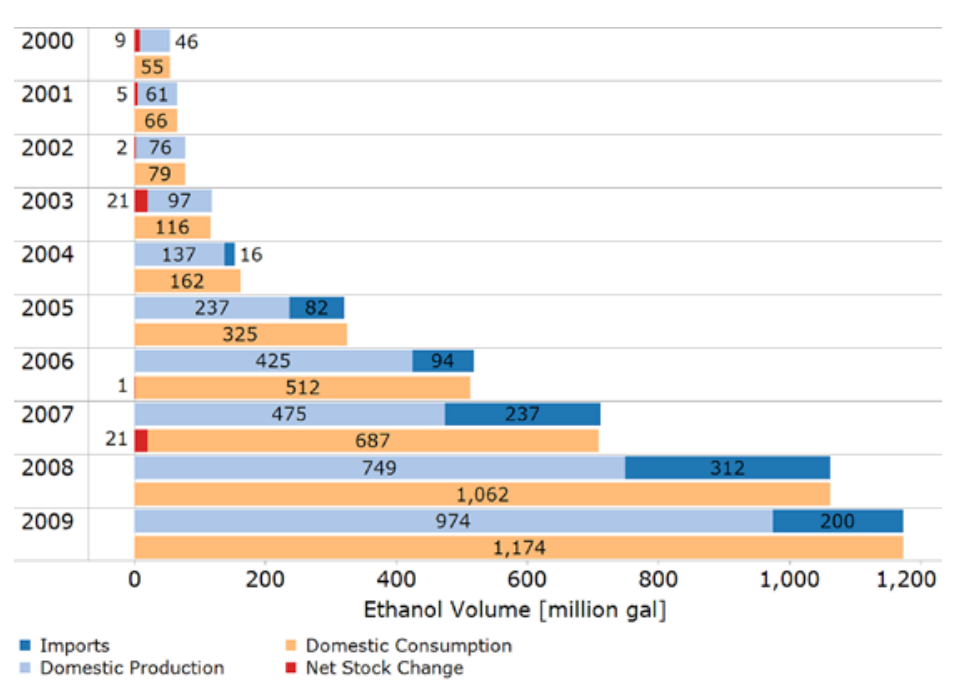

Figure 5. EU biodiesel trade balance 2000-2009 (Lamers et al. 2011)

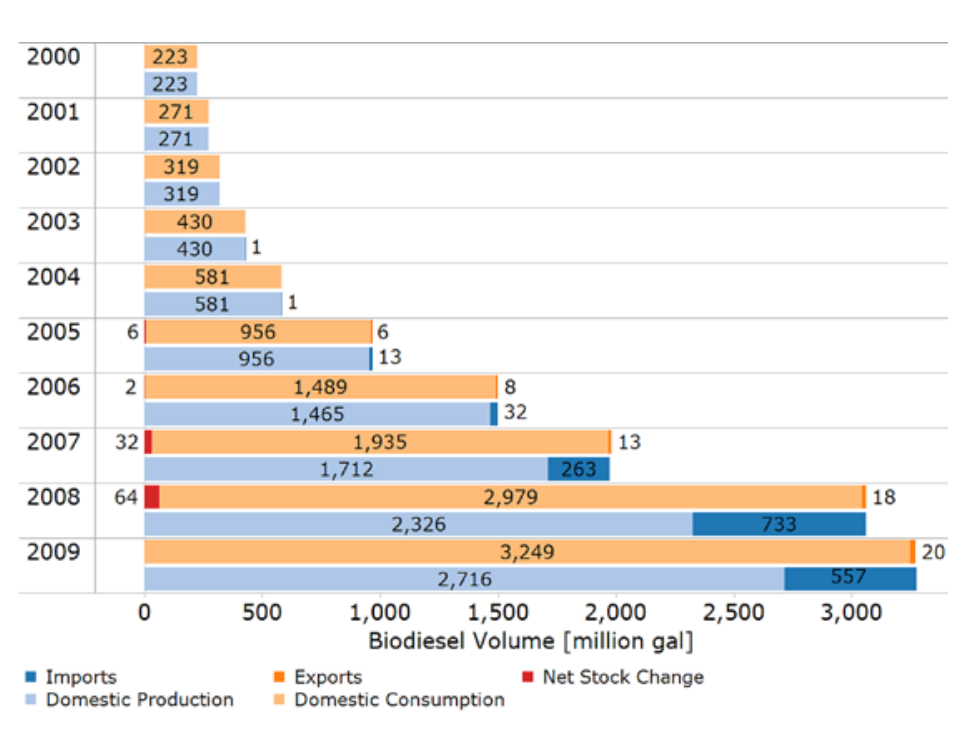

\section{Argentina}

Unlike Brazil, Argentina has primarily focused on exporting biodiesel. Argentina's policies have included tax credits for production as well as much lower export taxes than other vegetable oils (Lamers et al. 2011). The result has been an industry focused on export primarily to the EU-often via the United States (Junginger 2008). The RFS is not expected to greatly increase the demand for biodiesel in the United States, so most Argentinean biodiesel will likely continue to go to the EU. Argentina has implemented some policies 
encouraging domestic consumption, but production volumes are expected to remain high enough to continue its focus on exports (Lamers et al. 2011).

\section{Conclusion}

Ethanol and biodiesel trade have been driven largely by GHG emissions policies promoting biofuels production in the United States, EU, Brazil, and Argentina. Ethanol trade and production have faced more targeted policies and tariffs than biodiesel. Future developments of EU policies, especially concerning sustainability requirements, will likely have a large impact on the size of biofuels trade. The United States may import less biofuels with the expiration of the production tax credits and the saturation of ethanol use in gasoline blends. Exports from the United States will likely depend on the status of EU legislation and the production capacities of other producers, especially Brazil and Argentina.

\section{References}

Dunmore, C. (10 September 2012). EU to Limit Use of Crop-Based Biofuels Draft Law. Accessed September 20, 2012: www.reuters.com/article/2012/09/10/ us-eu-biofuels-idUSBRE8890SJ20120910

U.S. Energy Information Administration (EIA). (2012). Monthly Energy Review: August 2012. DOE/EIA-0035(2012/08). Washington, DC: U.S. Energy Information Administration. Accessed September 17, 2012: www.eia.gov/totalenergy/data/ monthly/pdf/mer.pdf

Heinimo, J.; Junginer, M. (2009). "Production and Trading of Biomass for Energy-An Overview of the Global Status.” Biomass and Bioenergy. (33:9); pp. $1310-1320$.

Junginger, M.; Bokesjø, T.; Bradley, D.; Dolzan, P.; Faaij, A.; Heinimo, J.; Hektor, B.; Leistad, Ø.; Ling, E.; Perry, M.; Piacente, E.; Rosillo-Calle, F.; Ryckmans, Y.; Schouwenberg, P.; Solberg, B.; Trømborg, E.; da Silva Walter, A.; de Wit, M. (2008). "Developments in International Bioenergy Trade." Biomass and Bioenergy. (32:8); pp. 717-729.

Lamers, P.; Hamelinck, C.; Junginger, M.; Faaij, A. (2011). “International Bioenergy Trade-A Review of Past Developments in the Liquid Biofuel Market." Renewable and Sustainable Energy Reviews (15:6); pp. 2655-2676.

U.S. International Trade Commission. (2011). "Caribbean Basin Economic Recovery Act: Impact on U.S. Industries and Consumers and on Beneficiary Countries Twentieth Report 2009-2010.” Investigation No. 332-227. Accessed on August 25, 2012: www.usitc.gov/publications/332/pub4271.pdf

National Renewable Energy Laboratory 15013 Denver West Parkway Golden, C0 80401

303-275-3000 • www.nrel.gov

NREL is a national laboratory of the U.S. Department of Energy, Office of Energy Efficiency and Renewable Energy, operated by the Alliance for Sustainable Energy, LLC.

NREL/BR-6A20-56792 • May 2013

Photos credits (page 1, left to right): iStock 13737597; Pat Corkery, NREL 16374; iStock 12123595; Toyota Motor Sales, USA, NREL 16933; Dennis Schroder, NREL 18229; Dennis Schroeder, NREL 19163

Printed with a renewable-source ink on paper containing at least $50 \%$ wastepaper, including $10 \%$ post consumer waste. 